\title{
Environmental and genetic determinant of otolith shape revealed by a non-indigenous tropical fish
}

\author{
Matthias Vignon ${ }^{1,2,4, *}$, Fabien Morat $^{1,3}$ \\ ${ }^{1}$ UMR 5244 CNRS EPHE UPVD, Biologie et Écologie Tropicale et Méditerranéenne, Université de Perpignan Via Domitia, \\ 66860 Perpignan cedex, France \\ ${ }^{2}$ UMS 2978 CNRS EPHE, Centre de Recherches Insulaires et Observatoire de l'Environnement (CRIOBE), BP 1013, \\ Papetoai Moorea, French Polynesia \\ ${ }^{3}$ Present address: Centre d'Océanologie de Marseille, Université de la Méditerranée, UMR CNRS 6540, Campus de Luminy, \\ Case 901, 13288 Marseille cedex 09, France \\ ${ }^{4}$ Present address: UMR ECOBIOP INRA-UPPA, Ecologie Comportementale et Biologie des Populations de Poissons, \\ (1) Pôle d'Hydrobiologie de Saint Pée sur Nivelle, INRA, Quartier Ibarron, 64310 Saint Pée sur Nivelle, France; \\ (2) UPPA, UFR Sciences \& Techniques de la Côte Basque, 1 Allée du parc Montaury, 64600 Anglet, France
}

\begin{abstract}
Otolith morphometrics have been shown to provide a practical basis for stock discrimination and subsequent fisheries management. However, the determinants of otolith shape are not fully understood and analysis does not distinguish between genotype and environmentally induced differences. In this context, understanding how those 2 components act synergetically on the otolith shape is fundamental. The use of non-indigenous fish of multiple origins provides an interesting tool for evaluating the relative importance of genetic and environmental components in determining otolith shape. This paper investigates to what extent a dual regulation (i.e. genetic and environmental) of the otolith shape from an introduced coral reef snapper (Lutjanus kasmira) exists, in order to determine how each component specifically acts on otolith morphology. Using geometric morphometrics, we discriminated between native and introduced range as well as between individuals belonging to different lineages (i.e. origins) but growing under the same environmental conditions (individuals cohabiting within the same shoals in the wild). Here we show that both genetic and environmental influences play a substantial role in determining the shape of the otolith. More specifically, while environment induces an overall change in otolith shape, genetically induced changes locally affect otolith shape. In addition, data suggest that both nuclear and mitochondrial components act synergetically. This information is fundamental if otolith shape is to be used as an effective tool for management of fisheries resources in the future.
\end{abstract}

KEY WORDS: Fisheries management · Stocks · Geometric morphometrics · Lutjinidae · French Polynesia $\cdot$ Hawaiian archipelago $\cdot$ Evolutionary

Resale or republication not permitted without written consent of the publisher

\section{INTRODUCTION}

Otolith analysis is an important and widely used tool in numerous ichthyological studies. It provides accurate estimates of age and growth at both the daily and the yearly scale and a basis for a record of the growth patterns in individuals, cohorts and populations (Campana \& Thorrold 2001). Moreover, variation in otolith shape is also a useful tool for discriminating between species (L'Abée-Lund 1988, Stransky \& MacLellan 2005, Tuset et al. 2006) and fish stocks (Campana \& Casselman 1993, DeVries et al. 2002, Cardinale et al.
2004, Tracey et al. 2006, Burke et al. 2008). Since otoliths are used for these different purposes, it is important to determine the factors that affect their shape variability. Features containing stock-specific information such as annuli spacing are biologically interpretable (i.e. related to age and growth), whereas other features such as otolith shape are not since its determinants are not fully understood. Thus, although stock discriminations made using otolith morphometric are common, the reasons for such differences are rarely known. Nevertheless, there is growing interest in the use of otolith shape as a natural tag of fish stocks 
(Cadrin 2000, Begg et al. 2005, Campana 2005) because it provides a practical basis for stock separation that is useful in fisheries management (Begg \& Waldman 1999).

It is currently recognised that otolith growth and shape occurs under dual regulation: overall shape is regulated genetically, but there is a strong variability related to environmental factors. A number of authors have suggested that otolith shape is genetically constrained, species specific and reflects phylogenetic relationships (Lombarte \& Castellón 1991, Lombarte \& Lleonart 1993, Reichenbacher et al. 2009). However, otoliths present variation among conspecific individuals, being mainly influenced by sex, age, year class and stock (Castonguay et al. 1991, Begg \& Brown 2000, Monteiro et al. 2005) as well as by local environmental conditions or factors such as depth, water temperature and substrate type (Lombarte \& Lleonart 1993, Gagliano \& McCormick 2004, Mérigot et al. 2007, Hüssy 2008). Although several studies have indicated that otolith shape differences between stocks are likely to be caused by both environmental and genetic influences, it is unclear to what extent and how they affect otolith shape (Begg \& Brown 2000, Simoneau et al. 2000). In general, analysis does not distinguish between genetic and environmentally induced differences (Campana \& Casselman 1993, Cardinale et al. 2004).

There are few comprehensive reports that consider the relative importance of genetic/environmental effects on otolith shape in particular fish species in the context of stock discrimination (Burke et al. 2008). Several studies were based on theoretical considerations and indirect evidence, implying that otolith shape variation is determined to some degree by genetics. Only a limited number of studies have directly investigated the determinants of otolith shape. Cardinale et al. (2004) used hatchery cod Gadus morhua released into the wild that were recaptured after several years to demonstrate that both genetic and environmental influences control otolith shape. However, the design of experiments such as those performed by Cardinale et al. (2004) is a logistically heavy and expensive task. Alternatively, the study of non-indigenous species could provide an interesting approach to evaluate the relative importance of genetic and environmental influences control on otolith shape, especially when species of multiple origins (with distinct evolutionary history and genetics) were introduced in the same area and thus share the same environment.

The Hawaiian Islands are among the most geographically and hydrographically isolated in the world and thus exhibit an unusual reef fish assemblage. This isolation has resulted in some major reef fish taxa being totally absent or poorly represented. Further- more, the Hawaiian Islands lack the reef fish species that support valuable commercial and recreational fisheries on other islands of the Indo-Pacific area: e.g. shallow-water groupers and snappers (Oda \& Parrish 1981, Coleman et al. 2000). Therefore, in the late 1950s, the Hawaiian government introduced various reef fishes to the Hawaiian Islands from French Polynesia to enhance local fisheries. Among the species intentionally introduced from Polynesia to the Hawaiian Islands, the bluestripe snapper Lutjanus kasmira became established (Randall 1987), rapidly spread throughout the Windward Islands and became extremely abundant (Friedlander et al. 2002, Schumacher \& Parrish 2005). Between 1955 and 1961, 3200 L. kasmira were transported from the Society Islands (Moorea, 728 ind.) and the Marquesas Islands (Nuku Hiva, 2472 ind.) to Hawaii (O'ahu). When comparing the 2 source populations, molecular analysis revealed a strong population structure in the nuclear and mitochondrial genome (Planes \& Lecaillon 1998, Gaither et al. 2009). On the basis of the high level of genetic divergence between the 2 source populations, authors have demonstrated that descendants of fish from both the Society and the Marquesas Islands have colonized the Hawaiian archipelago with seemingly equal success in a panmictic way (i.e. the 2 lineages are freely interbreeding, see Gaither et al. 2010). In the introduced range, the different lineages cohabit within the same shoals in the wild, thus growing under the same environmental influence.

The present study investigates whether a dual regulation (genetic and environmental) of the shape of the otoliths from a coral reef snapper Lutjanus kasmira occurs, in order to determine how each factor acts on otolith morphology. To do this, on the basis of geometric morphometrics, discriminant analyses were performed between native and introduced range as well as between individuals belonging to different nuclear and mitochondrial lineages in the introduced range but growing under the same environmental influence (i.e. ind. cohabiting within the same shoals).

\section{MATERIALS AND METHODS}

Sites and host collection. A total of 95 Lutjanus kasmira were caught during 2006 and 2007 in the native and introduced range: 37 ind. from the north coast of Moorea Island $\left(17^{\circ} 30^{\prime} \mathrm{S}, 149^{\circ} 50^{\prime} \mathrm{W}\right.$; Society Archipelago, French Polynesia), 21 ind. from the Marquesas Islands $\left(8^{\circ} 57^{\prime} \mathrm{S}, 139^{\circ} 35^{\prime} \mathrm{W}\right.$; near Ua Huka, French Polynesia) and 37 ind. from the south coast of $\mathrm{O}^{\prime} \mathrm{ahu}$ (21 $17^{\prime} \mathrm{N}, 157^{\circ} 53^{\prime} \mathrm{W}$; Hawaiian Archipelago) (Fig. 1). All fish were speared at a depth ranging between 10 and $20 \mathrm{~m}$. Because ontogenetic allometry has been 


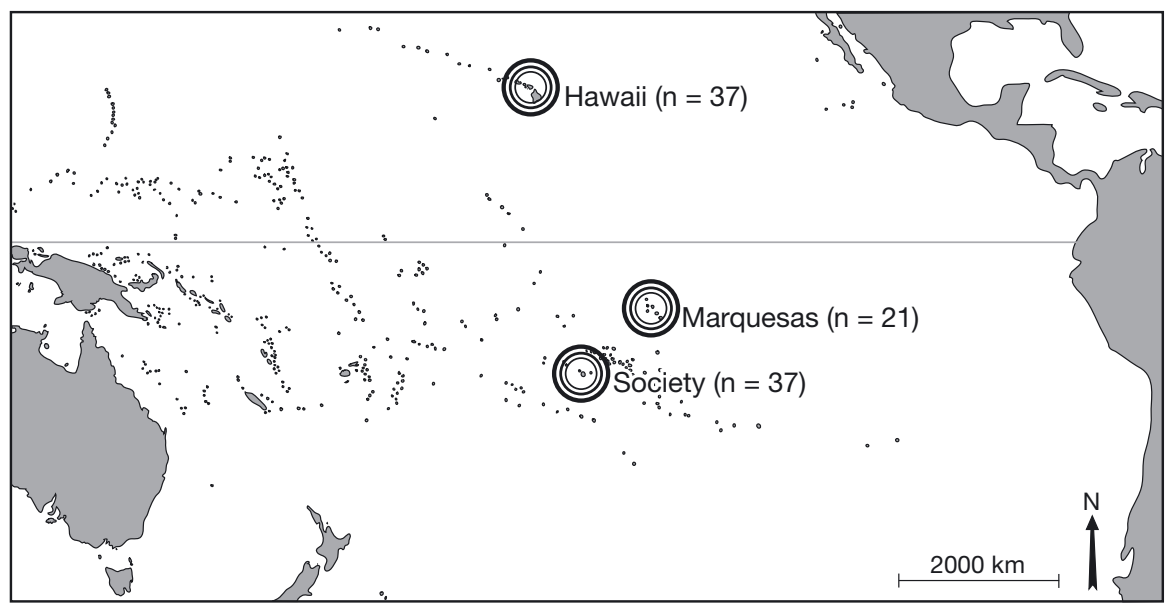

Fig. 1. Sampling locations in the Pacific Ocean and number of collected fish

considered an important confounding effect in otolith shape determination (Simoneau et al. 2000, Monteiro et al. 2005), only fish with a standard length between 25 and $30 \mathrm{~cm}$ (i.e. 4 to $5 \mathrm{yr}$ old) were collected and subsequently included in the data analysis. Standard length $\left(L_{\mathrm{S}}\right)$ and total length $\left(L_{\mathrm{T}}\right)$ of individuals were measured to the nearest $\mathrm{mm}_{\text {; }}$ total $\left(W_{\mathrm{T}}\right)$ and eviscerated weight $\left(W_{\mathrm{e}}\right)$ was measured to the nearest $\mathrm{g}$. Fulton's condition index $(K)$ was calculated as: $W_{\mathrm{e}}=K / L_{\mathrm{S}}{ }^{3}$ (Bolger \& Connolly 1989). The age of individuals was estimated during this study and all otolith readings were conducted on sectioned sagittae. Sectioning and counting were carried out according to Morales-Nin (1989).

Genetic analyses. Fin clips of all individuals were collected and stored in $75 \%$ ethanol. Total genomic DNA was extracted using the genomic DNA purification kit EZNA® (Omega Biotek), based on the protocol of DNA purification from 5 to $10 \mathrm{mg}$ of fresh stored tissue. We used both mtDNA sequences, to track the origin of individuals, and nDNA sequences, to examine introgression between the 2 origins. For each individual, a 367 base pair fragment of the mitochondrial control region I (Dloop) and a 152 base pair fragment of the growth hormone $(\mathrm{GH})$ gene intron was sequenced. The 5' end of Dloop was PCR amplified with the primers CRA (5'-TTC CAC CTC TAA CTC CCA AAG CTA-3' and CRE (5'-CCT GAA GTA GGA ACC AGA TG-3'). Amplification was performed on an Mastercycler® Gradient (Eppendorf) in a $25 \mu \mathrm{l}$ reaction volume containing $2.5 \mu$ l of $10 \times$ buffer $\left(1.5 \mathrm{mM} \mathrm{Mg}^{2+}\right), 200 \mu \mathrm{M}$ of each $\mathrm{dNTP}, 0.5 \mathrm{mM} \mathrm{MgCl}_{2}, 0.5 \mu \mathrm{M}$ of each primer, $1 \mathrm{U}$ Taq DNA polymerase and $1.2 \mu \mathrm{l}$ genomic DNA template. A modified hot-start PCR with an initial soak at $94^{\circ} \mathrm{C}$ for 5 min was followed by 40 cycles consisting of denaturation at $94^{\circ} \mathrm{C}$ for $1 \mathrm{~min}$, annealing at $51^{\circ} \mathrm{C}$ for $1 \mathrm{~min} 15 \mathrm{sec}$ and extension at $72^{\circ} \mathrm{C}$ for $2 \mathrm{~min}$. The PCR was ended by a final extension at $72^{\circ} \mathrm{C}$ for $5 \mathrm{~min}$. The GH intron was amplified using the primers GH5-F (5'AGG CCA ATC AGG AGG GAG-3') and GH6-R (5'TGC CAC TGT CAG ATA AGT CTC C-3'). Amplification was this time performed in a $30 \mu$ reaction volume containing $3 \mu \mathrm{l}$ of $10 \times$ buffer $\left(1.5 \mathrm{mM} \mathrm{Mg}^{2+}\right), 200 \mu \mathrm{M}$ of each dNTP, $1.67 \mathrm{mM} \mathrm{MgCl}_{2}, 0.33 \mu \mathrm{M}$ of each primer, $1 \mathrm{U}$ Taq DNA polymerase and $2 \mu \mathrm{l}$ genomic DNA template. The modified hot-start PCR consisted of an initial soak at $94^{\circ} \mathrm{C}$ for $2 \mathrm{~min}$, followed by 40 cycles of $94^{\circ} \mathrm{C}$ for $1 \mathrm{~min}, 51^{\circ} \mathrm{C}$ for $1 \mathrm{~min} 15 \mathrm{sec}, 72^{\circ} \mathrm{C}$ for $2 \mathrm{~min}$, as well as a final extension at $72^{\circ} \mathrm{C}$ for another $2 \mathrm{~min}$. Quality and quantity of both Dloop and $\mathrm{GH}$ intron PCR products were determined on a $2 \%$ TBE $(0.5 \times)$ agarose gel with $2 \%$ ethyl bromine (EtBr).

Otolith shape analysis. Each unbroken otolith was cleaned, placed with the sulcus acusticus oriented towards the observer and then examined under a stereomicroscope fitted with a digital camera (XC$77 \mathrm{CE}$ ) linked to a computer. The high contrast images were thresholded and binarized for contour extraction by ImageJ software (freely available at http://rsb. info.nih.gov/ij/). While shape analyses of otolith 2D contour are generally performed through Fourier analysis, otoliths have also been successfully studied using geometric morphometrics (Monteiro et al. 2005, Ponton 2006). Because Fourier analysis can be an effective method for describing outline shapes, but does not encourage intuitive understanding of the reason for subtle shape differences (Cadrin \& Friedland 1999, Tuset et al. 2006, but see Parisi-Baradad et al. 2005), we used geometric morphometrics for a direct comparison of shape differences. This useful technique appears to be effective for shape discrimination and allows visualization and quantification of shape information (Monteiro et al. 2005, Ponton 2006). 
Following Monteiro et al. (2005), the outline of each specimen was stored as pixel coordinates that were reduced to 100 points equally spaced (using contour length as a parameter) along the contour, starting at the intersection of the major axis with the anterior margin of the otolith. This reference point (biologically corresponding among individuals) is referred to as a landmark and the remaining 99 points as semi-landmarks. The coordinates of the landmark and semi-landmarks were digitized using the software tpsDig version 2.10 (from the TPS package, Rohlf 2006). Generalized orthogonal least square Procrustes superimpositions of landmark and semi-landmark coordinates were then computed with tpsRelw version 1.45, minimizing bending energy with respect to a mean reference form (Green 1996, Bookstein 1997) to determine the criteria for sliding semi-landmarks along outlines. The geometric size of each specimen was estimated by the centroid size, defined as the square root of the sum of squared distances from all landmarks to the centroid of the configuration (Bookstein 1991). Although the sampled fish were of the same size, a Kruskal-Wallis test with Dunn's post hoc test was performed to compare size, age and condition index of collected fish among populations and lineages. In addition, centroid size of otoliths was tested for differences among populations and lineages using MANOVA. To explore otolith shape variation among populations and lineages, we performed a canonical variate analysis (CVA) using the software CVAGen version 6o (from the integrated morphometrics package [IMP], Sheets 2003) with the method of dimensionality reduction based on principal component analysis (PCA) (Sheets et al. 2006). Statistical significance of the CVA was tested using Bartlett's test for differences in the value of Wilk's $\lambda$. To visualize localized otolith shape differences among populations-lineage, we generated thin-plate spline deformation grids (Bookstein 1991) with scaling option $\alpha=0$ (Rohlf \& Marcus 1993) along the first canonical axis using tpsRegr. Thin-plates were exaggerated (magnification) for clarity.

To separately test the effect of mitochondrial and nuclear origin on otolith shape in the introduced range, we computed a regression of the partial warps onto dummy variables corresponding to groups (i.e. -1 and 1 for Marquesas and Society mitochondrial lineages and $-1,0,1$ for Marquesas, hybrids and Society nuclear lineages, respectively) using tpsReg version 1.31.

On theoretical and physiological bases, it is reasonable to assume that genetic constraints act symmetrically on the 2 otoliths. In contrast, it is not obvious and there is no a priori reason to consider that environment and interaction between environment and genetics affect otoliths in a symmetric way. As a consequence, left and right otoliths were analyzed separately and covariation in shape between the 2 sides was assessed using partial least-squares (Rohlf \& Corti 2000). This has been performed for pairwise comparisons between populations and lineages, using mean shape of each group following CVA. In addition, hierarchial disparity (i.e. partitioning of morphological variation into contributions from 2 or more subgroups) based on landmarks and semi-landmarks was used to assess the amount of variation due to differences between left and right otoliths in each population and through all collected fish. Disparity was evaluated using Foote's (1993) disparity measurement based on Procrustes distance, with DisparityBox6i from the IMP package (Sheets 2003). To determine the disparity due to differences between left and right otoliths, one simply sums the contributions to the disparity of the 2 sides compared to overall disparity in the population.

\section{RESULTS}

All fish collected were of the same size, age and condition index among localities and lineages (KruskallWallis, $p>0.1$ ). In addition, centroid size of otoliths did not significantly differ between localities and lineages (MANOVA, p > 0.1), avoiding ontogenic bias. First, CVA made it possible to discriminate between the 3 populations (including native and introduced ranges) on the basis of both left and right otolith (Fig. 2. Left otolith axis 1: $\lambda=0.633, \chi^{2}=41.576, \mathrm{df}=6, \mathrm{p}<0.001$; axis 2 : $\lambda=0.854, \chi^{2}=14.338, \mathrm{df}=2, \mathrm{p}<0.001$. Right otolith axis $1: \lambda=0.693, \chi^{2}=35.215, \mathrm{df}=6, \mathrm{p}<0.001$; axis 2 : $\lambda=0.879, \chi^{2}=13.950, \mathrm{df}=2, \mathrm{p}<0.001$ ). Differences between populations include major reshaping of overall otoliths along their contour as illustrated by the thin-plates (Fig. 2). In the introduced range, molecular analysis among the 37 ind. collected revealed 5 distinct genotypes (among the 6 possible genotypes) (Table 1). Unfortunately, no individual with mitochondrial and nuclear Society origin (true Society lineage) was collected. Second, CVA made it possible to discriminate between the 5 genotypes in the introduced range,

Table 1. Haplotypes of the 37 ind. collected in Hawaii, indicating the origin of mitochondrial (Dloop) and nuclear (GH intron) sequences

\begin{tabular}{|c|c|c|c|c|}
\hline & & $\begin{array}{l}\text { Mitocho } \\
\text { Marquesas }\end{array}$ & $\begin{array}{l}\text { ndrial } \\
\text { Society }\end{array}$ & Total \\
\hline \multirow{4}{*}{ 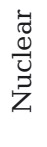 } & Marquesas-Marquesas & 10 & 2 & 12 \\
\hline & Marquesas-Society & 15 & 8 & 23 \\
\hline & Society-Society & 2 & 0 & 2 \\
\hline & Total & 27 & 10 & \\
\hline
\end{tabular}




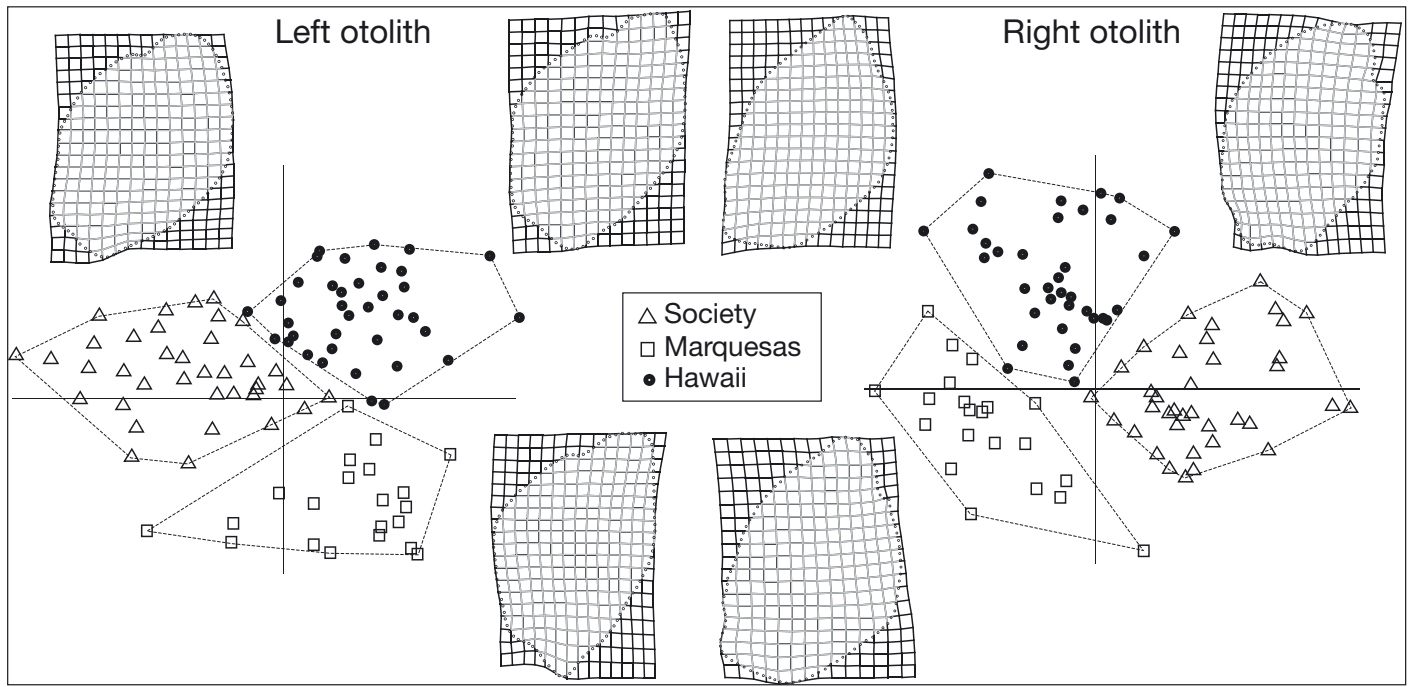

Fig. 2. Canonical variates analysis among the 3 populations for left and right otoliths. The transformation grids (thin-plate) show the shape changes of the populations along the 2 first discriminant functions ( $3 \times$ magnification)

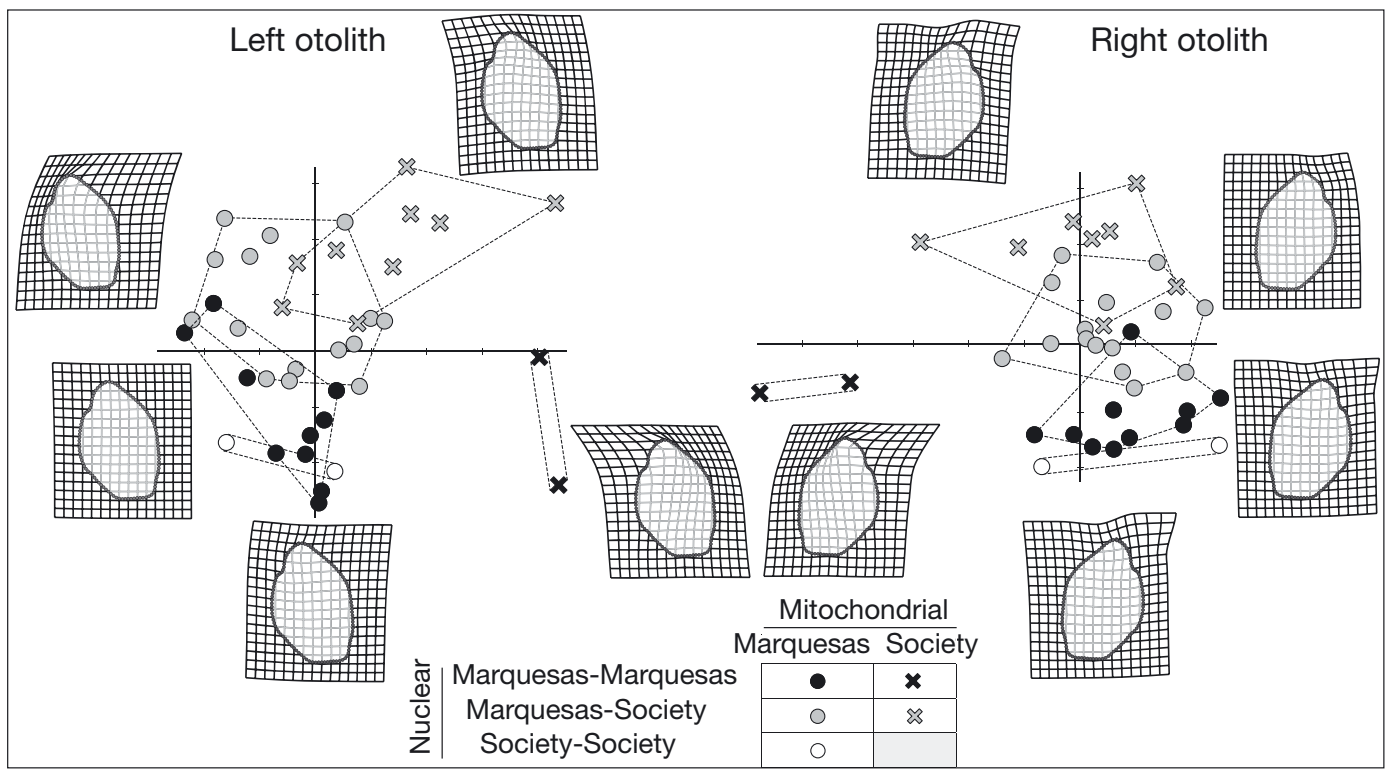

Fig. 3. Canonical variates analysis among the 5 haplotypes found in the introduced range for left and right otoliths

including hybrids (Fig. 3. Left otolith axis 1: $\lambda=0.155$, $\chi^{2}=57.834, \mathrm{df}=20, \mathrm{p}<0.001$; axis $2: \lambda=0.333, \chi^{2}=$ 34.104, $\mathrm{df}=12, \mathrm{p}<0.001$; axis 3: $\lambda=0.579, \chi^{2}=0.879$, $\mathrm{df}=6, \mathrm{p}<0.01$. Right otolith axis 1: $\lambda=0.208, \chi^{2}=$ 48.648, df $=20, \mathrm{p}<0.001$; axis $2: \lambda=0.427, \chi^{2}=33.381$, $\mathrm{df}=12, \mathrm{p}<0.001)$.

In addition to shape separation of haplotypes by the discriminant analysis, regression revealed a significant and distinct effect of mitochondrial (Generalized Goodall $F$-test; left otolith: $F=1.308$, df $=196,6860, \mathrm{p}=$ 0.0028 ; right otolith: $F=1.836, \mathrm{df}=196,6860, \mathrm{p}<0.001$ ) and nuclear origin (Generalized Goodall F-test; left otolith: $F=1.864$, df $=196,6860, \mathrm{p}<0.001$; right otolith: $F=1.308, \mathrm{df}=196,6860, \mathrm{p}<0.001)$. In contrast to differences between islands, which involve reshaping of overall otoliths along their contour, otolith shape differences mainly involve the rostrum and antirostrum, respectively for mitochondrial and nuclear lineages (Fig. 4). This pattern is consistent for the 2 sides with the same information provided by the left and right otoliths, as characterized by a high co-variation for all pairwise differences tested, reaching as high as $86 \%$. 


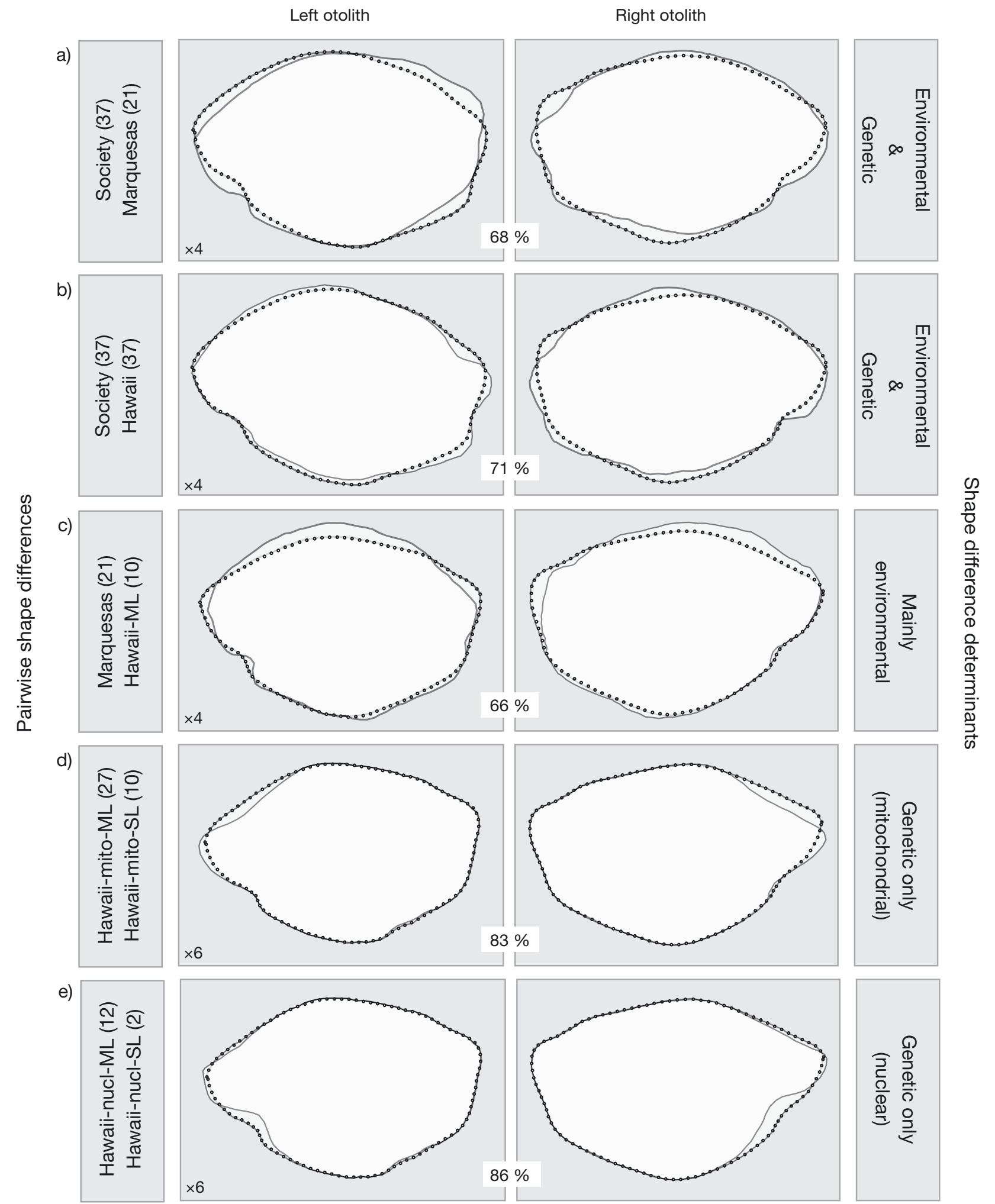

Fig. 4. Pairwise shape differences between populations and lineages for left and right otolith (no. of ind. per population of lineage indicated in brackets). Percentage: co-variation pattern between the 2 sides using partial least-squares. ML: Marquesas Lineage; SL: Society Lineage; mito: mitochondrial; nucl: nuclear. Shape determinants: main factors affecting otolith shape. Magnification (difference exaggeration): $\times 4$ or $\times 6$. Lines: first (continuous) and second (dotted) population/lineage 
Moreover, differences between left and right otoliths accounted for only $13.4 \%$ total shape disparity through the 3 populations $(12.9,11.1$ and $21.0 \%$ for the intrapopulation variability from Society, Marquesas and Hawaii respectively), emphasizing that little of the otolith shape variation is due to differences between the 2 sides.

\section{DISCUSSION}

\section{Otolith shape determinants}

Non-indigenous fish, deliberately introduced from multiple locations, provide an interesting tool that may prove helpful for evaluating the relative influence of genetic and environmental conditions on otolith shape. The Hawaiian population includes 2 genetically distinct lineages that were historically introduced in the archipelago at the end of the 1950s. While differences between fish from the 2 archipelagos in the native range (i.e. Society and Marquesas Islands) are likely to be caused by both environmental and genetic influences, differences between native and introduced range within each lineage are mostly or even solely influenced by contrasting environmental conditions, as several authors found no indication of an important loss of genetic diversity either during the initial introduction or during the subsequent 50 yr (Planes \& Lecaillon 1998, Gaither et al. 2010). In addition, individuals belonging to different lineages within the Hawaiian Archipelago, but growing under the same environmental conditions and cohabiting within the same shoal, revealed the genetic (i.e. evolutionary) basis of otolith shape. This study confirms the hypothesis that otolith shape in fish occurs under dual regulation (i.e. genetic and environmental). According to our discriminant analysis, while overall otolith outline can be reshaped by contrasting environmental conditions, intra-specific genetic variations due to long-time separation only affect otolith shape locally, mainly in the rostrum and antirostrum parts. Ultimately, the hybridization between the 2 lineages may allow assessment of the relative influence of nuclear and mitochondrial DNA in determining otolith shape. The present data do indeed suggest a dissociated nuclear and mitochondrial effect. However, we recognize that only a few individuals per haplotype have been studied, and these analyses suffer from the lack of individuals with both mitochondrial and nuclear DNA originating from the Society Archipelago (true Society lineage). This specific point needs further investigation.

While there is no a priori reason to consider that the main determinants of otolith shape act in a symmetric way, we found a high degree of co-variation between left and right otoliths for all pairwise differences tested. This reveals that genetics, environment and interaction between environment and genetics act symmetrically on the 2 otoliths. This has major implication because fluctuating asymmetry (i.e. random deviations from perfect symmetry) in otoliths has become a popular tool with which to examine the effects of stress during the development of fish and a possible indicator of fitness (e.g. Lemberget \& McCormick 2009, Palmer et al. 2010 and references therein). Here, we provide strong evidence that right and left otoliths carry the same kind of information with regard to environmental and genetically-based variations. We also provide an estimation of the basal level of variability naturally occurring between left and right otoliths in natural populations.

On a theoretical basis, genetic regulation of otolith shape was already suspected as the deposition of material in the otolith is an extracellular process involving glycoprotein matrix, which is under different physiological control from somatic cellular growth. Several genes involved in the biomineralization of otoliths have already been discovered (Söllner et al. 2003). Yet most evidence is indirect and mainly based on interspecific variations between congeneric species, as otolith shape is species specific and reflects phylogenetic relationships (Lombarte \& Castellón 1991, Lombarte \& Lleonart 1993). However, the reason for such intraspecific stability may be a biological constraint posed by its function as a sound transducer (Gauldie 1988, Lychakov \& Rebane 2000). For some species, the level of classification success obtained using otolith shape analysis increases with the extent of genetic discreteness or geographic separation displayed by study groups (Castonguay et al. 1991, Friedland \& Reddin 1994), implying that otolith shape variation is determined by genetics to at least some degree. Another indirect example comes from Turan (2000) who observed a direct relationship between phenotypic divergence and geographical separation of herring Clupea harengus in the Northeast Atlantic using meristics and truss measurements of otoliths. The same kind of analysis was performed by Reichenbacher et al. (2009) with freshwater cyprinodontid Aphanius dispar from the Arabian Peninsula. In fact, only a limited number of studies have directly investigated the determinants of otolith shape. To date, an important experimental study has been performed by Cardinale et al. (2004); these authors used hatchery releases of Atlantic cod Gadus morhua into the wild, recaptured after several years, to demonstrate that both genetic and environmental influences control otolith shape.

Moreover, substantial otolith shape differences have also been observed between groups of fish that are close in terms of geographical distribution (Galley et 
al. 2006, Pothin et al. 2006, Vignon et al. 2008) and for stocks that could not be separated using genetic techniques (DeVries et al. 2002). Otolith shape differences between reared and wild cod Gadus morhua (Cardinale et al. 2004), flounder Paralichthys olivaceus (Katayama \& Isshiki 2007) and lake trout Salvelinus namaycush (Simoneau et al. 2000) also highlight how environmental factors such as temperature and feeding conditions can produce otolith shape variation in the absence of genetic differences. Consequently, shape analysis of the otolith indicates which environment a fish has experienced during its life history, and groups of fish that maintain distinct distributions for part or all of their lives can be discriminated (Turan 2000, DeVries et al. 2002, Cardinale et al. 2004, Berg et al. 2005, Stransky \& MacLellan 2005). The advantage otolith shape offers is that otoliths constitute a permanent record and no resorption occurs. However, some morphometric differences between fish reared in rivers as opposed to open water environments appear to have a genetic basis (Cadrin 2000). Otolith shape does not necessarily reflect genetic differences (Stransky 2005). Otoliths present variations among conspecific individuals and numerous confounding effects have been pointed out: sex, body condition, age, year class, stock (Castonguay et al. 1991, Begg \& Brown 2000, Monteiro et al. 2005), as well as different local environmental conditions or factors such as food availability, depth, water temperature and substrate type (Lombarte \& Lleonart 1993, Begg et al. 2001, Gagliano \& McCormick 2004, Mérigot et al. 2007, Burke et al. 2008, Hüssy 2008, Schulz-Mirbach et al. 2008).

Ultimately, data suggest that otolith development occurs under dual regulation; while genetics influence the form of the otolith itself, environmental conditions regulate the quantity of material deposited during the formation of the otolith in terms of a metabolic expression and physical constraint. In other words, environmental effects essentially alter the rates of somatic and otolith growth, which in turn affect otolith shape. Several studies have documented a link between otolith shape differences and somatic growth rates, due to the proportional relationship between otolith growth and somatic growth mediated by local environmental conditions (Campana \& Casselman 1993, Oozeki \& Watanabe 2000, Simoneau et al. 2000, Strelcheck et al. 2003, Cardinale et al. 2004). For example, Gauldie \& Nelson (1990) found that faster growth produced long thin crystals compared with shorter more compacted ones in slower-growing fish, which could influence the overall shape of the developing otolith. In our study, differences among populations and lineages were controlled for ontogenic (fish length, age and otolith centroid size) and somatic (condition index) bias. In this context, the genetic basis of otolith shape may result from differences in physiology or subtle somatic cellular growth, potentially influenced by both nuclear and mitochondrial DNA.

\section{Fisheries management}

The concept of 'stock' is a useful taxonomic grouping that is considered fundamental for the purposes of management of fisheries resources and endangered species. While the terms 'stock' and 'population' are currently used rather interchangeably, the stock concept really has to do with the interaction between a fish species and its management (Begg \& Waldman 1999, Hammer \& Zimmermann 2005). In fisheries science, 'stock' first referred to any group of a fish species that is available for exploitation in a given area. Modern stock definition refers to arbitrary groups of fish with members of each group having similar life history characteristics (Begg \& Waldman 1999). However, it also integrates genetic knowledge, recognizing the importance of information on population structure, including parental and evolutionary linkages (Law 2000, Waples \& Naish 2009). Thus, the number and geographic limits of non-interbreeding, 'panoceanic' populations or self-recruiting populations within an exploited species are of interest to characterize stocks as management units (Ovenden 1990, Carvalho \& Hauser 1994).

On the one hand, genetic differences between individuals, stocks and populations offer a basis for ascertaining the degree of reproductive isolation, which is the fundamental mechanism structuring differences between these taxonomic groups (Ryman 1991, Begg \& Waldman 1999). The strengths of genetic signals between stocks are positively associated with time since divergence of stocks and their degree of isolation. Thus, recent divergence or substantial secondary reproductive contact results in no apparent differences in gene frequencies between groups, even when it occurs. Ignoring such evolutionary linkages can contribute to erroneous, ineffective fisheries management (Ryman 1991, Hüssy 2008). On the other hand, the recognition of intraspecific groups with different life histories is important, despite the appearance of genetic homogeneity (Cadrin \& Friedland 1999), because of the basic assumption that the fishery targets a unit stock with definable patterns of recruitment and mortality. Therefore, intraspecific groups with stable differences in life history need to be identified to accurately model population dynamics for fishery stock assessment and management, regardless of genetic differences or similarities. In fact, phenotypic differences do not always result from genetic divergence, and groups defined by morphometric differ- 
ences may not indicate reproductively isolated populations.

Several authors have stressed that the understanding of the stock structure of a given fish species is crucial for outlining pertinent and appropriate management regulations in those fisheries where multiple stocks are differentially exploited at the same time and in those resources that straddle international boundaries (Dankel et al. 2008). There are many cases in which intensive exploitation, combined with ineffective fisheries management, has resulted in depletion of fish stocks (Begg \& Waldman 1999). In this context, numerous authors have investigated the shape of otoliths in order to assess its use for distinguishing between different stocks. The challenge for the future of morphometric stock identification is to develop a consensus on biological interpretations of geometric analyses (Cadrin 2000). Because the use of otolith shape analysis for stock identification is based on the confounding interaction between genetically and environmentally induced differences, the quantitative measurement of otolith shape determinants calls for special consideration and further investigation. Such information is crucial if otolith shape is to be used in the future as an effective tool to improve our understanding of the integrity of fish populations and the management of fisheries resources. When the results of different stock identification studies are not consistent, the default management scenario should be to use a precautionary approach to ensure resource sustainability and maintenance of genetic biodiversity. Therefore, the need for a holistic approach to fish stock identification, involving a broad spectrum of complementary techniques, has been suggested (Coyle 1998, Begg \& Waldman 1999), and this would maximize the likelihood of correctly defining stocks. Stock identification should be considered on a case-by-case multidisciplinary basis, involving genetics, biometrics and life history studies.

Acknowledgements. We are grateful to R. Lecomte-Finiger for revising this manuscript. The authors thank V. Messmer for her help in sequencing the GH intron and anonymous reviewers who made valuable suggestions to improve the manuscript.

\section{LITERATURE CITED}

Begg GA, Brown RW (2000) Stock identification of haddock Melanogrammus aeglefinus on Georges Bank based on otolith shape analysis. Trans Am Fish Soc 129:935-945

Begg GA, Waldman JR (1999) An holistic approach to fish stock identification. Fish Res 43:35-44

Begg GA, Overholtz WJ, Munroe NJ (2001) The use of internal otolith morphometrics for identification of haddock (Melanogrammus aeglefinus) stocks on Georges Bank. Fish Bull 99:1-14
Begg GA, Campana SE, Fowler AJ, Suthers IM (2005) Otolith research and application: current directions in innovation and implementation. Mar Freshw Res 56:477-483

Berg E, Sarvas TH, Harbitz A, Fevolden SE, Salberg AB (2005) Accuracy and precision in stock separation of north-east Arctic and Norwegian coastal cod by otoliths comparing readings, image analyses and a genetic method. Mar Freshw Res 56:753-762

Bolger T, Connolly PL (1989) The selection of suitable indices for the measurement and analysis of fish condition. J Fish Biol 34:171-182

Bookstein FL (1991) Morphometric tools for landmark data: geometry and biology. Cambridge University Press, Cambridge

Bookstein FL (1997) Landmark methods for forms without landmarks: localizing group differences in outline shape. Med Image Anal 1:225-243

Burke N, Brophy D, King PA (2008) Shape analysis of otolith annuli in Atlantic herring (Clupea harengus); a new method for tracking fish populations. Fish Res 91:133-143

> Cadrin SX (2000) Advances in morphometric identification of fishery stocks. Rev Fish Biol Fish 10:91-112

> Cadrin SX, Friedland KD (1999) The utility of image processing techniques for morphometric analysis and stock identification. Fish Res 43:129-139

Campana SE (2005) Otolith science entering the 21st century. Mar Freshw Res 56:485-495

Campana SE, Casselman JL (1993) Stock discrimination using otolith shape analysis. Can J Fish Aquat Sci 50:1062-1083

Campana SE, Thorrold SR (2001) Otoliths, increments, and elements: keys to a comprehensive understanding of fish populations? Can J Fish Aquat Sci 58:30-38

Cardinale M, Doering-Arjes P, Kastowsky M, Mosegaard H (2004) Effects of sex, stock and environment on the shape of known-age Atlantic cod (Gadus morhua) otoliths. Can J Fish Aquat Sci 61:158-167

Carvalho GR, Hauser L (1994) Molecular genetics and the stock concept in fisheries. Rev Fish Biol Fish 4:326-350

> Castonguay M, Simard P, Gagnon P (1991) Usefulness of Fourier analysis of otolith shape for Atlantic mackerel (Scomber scombrus) stock discrimination. Can J Fish Aquat Sci 48:296-302

Coleman FC, Koenig CC, Huntsman GR, Musick JA and others (2000) Long-lived reef fishes: the grouper-snapper complex. Fisheries 25:14-21

Coyle T (1998) Stock identification and fisheries management: the importance of using several methods in a stock identification study. In: Hancock DA (ed) Taking stock: defining and managing shared resources. ASFB, Sydney, p 173-182

Dankel DJ, Skagen DW, Ulltang Ø (2008) Fisheries management in practice: review of 13 commercially important fish stocks. Rev Fish Biol Fish 18:201-233

> DeVries DA, Grimes CB, Prager MH (2002) Using otolith shape analysis to distinguish eastern Gulf of Mexico and Atlantic Ocean stocks of king mackerel. Fish Res 57:51-62

Foote M (1993) Contributions of individual taxa to overall morphological disparity. Paleobiology 19:403-419

Friedland KD, Reddin DG (1994) Use of otolith morphology in stock discriminations of Atlantic salmon (Salmo salar). Can J Fish Aquat Sci 51:91-98

Friedlander AM, Parrish JD, DeFelice RC (2002) Ecology of the introduced snapper Lutjanus kasmira (Forsskal) in the reef fish assemblage of a Hawaiian bay. J Fish Biol 60:28-48

Gagliano M, McCormick MI (2004) Feeding history influences otolith shape in tropical fish. Mar Ecol Prog Ser 278: 291-296 
Gaither MR, Toonen RJ, Robertson DR, Planes S, Bowen BW (2009) Genetic evaluation of marine biogeographical barriers: perspectives from two widespread Indo-Pacific snappers (Lutjanus kasmira and Lutjanus fulvus). J Biogeogr 37:133-147

Gaither MR, Bowen BW, Toonen RJ, Planes S, Messmer V, Earle J, Robertson DR (2010) Genetic consequences of introducing allopatric lineages of bluestriped snapper (Lutjanus kasmira) to Hawaii. Mol Ecol 19:1107-1121

Galley EA, Wright PJ, Gibb FM (2006) Combined methods of otolith shape analysis improve identification of spawning areas of Atlantic cod. ICES J Mar Sci 63:1710-1717

Gauldie RW (1988) Function, form and time keeping properties of fish otoliths. Comp Biochem Physiol A 91:395-402

Gauldie RW, Nelson DGA (1990) Otolith growth in fishes. Comp Biochem Physiol A 97:119-135

Green WDK (1996) The thin-plate spline and images with curving features. In: Mardia KV, Gill CA, Dryden IL (eds) Proceedings in image fusion and shape variability techniques. Leeds University Press, Leeds, p 79-87

Hammer C, Zimmermann C (2005) The role of stock identification in formulating fishery management advice. In: Cadrin SX, Friedland KD, Waldman JR (eds) Stock identification methods. Applications in fishery science. Elsevier Academic Press, San Diego, CA, p 631-658

Hüssy K (2008) Otolith shape in juvenile cod (Gadus morhua): ontogenetic and environmental effects. J Exp Mar Biol Ecol 364:35-41

Katayama S, Isshiki T (2007) Variation in otolith macrostructure of Japanese flounder (Paralichthys olivaceus): a method to discriminate between wild and released fish. J Sea Res 57:180-186

L'Abée-Lund JH (1988) Otolith shape discriminates between juvenile Atlantic salmon, Salmo salar, and brown trout, Salmo trutta. J Fish Biol 33:899-903

Law R (2000) Fishing, selection, and phenotypic evolution. ICES J Mar Sci 57:659-668

Lemberget T, McCormick MI (2009) Replenishment success linked to fluctuating asymmetry in larval fish. Oecologia 159:83-93

Lombarte A, Castellón A (1991) Interspecific and intraspecific otolith variability in the genus Merluccius as determined by image analysis. Can J Fish Aquat Sci 69:2442-2449

> Lombarte A, Lleonart J (1993) Otolith size changes related with body growth, habitat depth and temperature. Environ Biol Fishes 37:297-306

Lychakov DV, Rebane YT (2000) Otolith regularities. Hear Res 143:83-102

Mérigot B, Letourneur Y, Lecomte-Finiger R (2007) Characterization of local populations of the common sole Solea solea (Pisces, Soleidae) in the NW Mediterranean through otolith morphometrics and shape analysis. Mar Biol 151: 997-1008

Monteiro LR, Di Beneditto APM, Guillermo LH, Rivera LA (2005) Allometric changes and shape differentiation of sagitta otoliths in sciaenid fishes. Fish Res 74:288-299

> Morales-Nin B (1989) Growth determination of tropical marine fishes by means of otolith interpretation and length frequency analysis. Aquat Living Resour 2:241-253

Oda DK, Parrish JD (1981) Ecology of commercial snappers and groupers introduced to Hawaiian reefs. Proc 4th Int Coral Reef Symp, Manila 1:59-67

> Oozeki Y, Watanabe Y (2000) Comparison of somatic growth and otolith increment growth in laboratory-reared larvae of Pacific saury, Cololabis saira, under different temperature conditions. Mar Biol 136:349-359

Ovenden JR (1990) Mitochondrial DNA and marine stock assessment: a review. Aust J Mar Freshwater Res 41: 835-853

Palmer M, Linde M, Morales-Nin B (2010) Disentangling fluctuating asymmetry from otolith shape. Mar Ecol Prog Ser 399:261-272

Parisi-Baradad V, Lombarte A, Garcia-Ladona E, Cabestany J, Piera J, Chic O (2005) Otolith shape contour analysis using affine transformation invariant wavelet transforms and curvature scale space representation. Mar Freshw Res 56:795-804

Planes S, Lecaillon G (1998) Consequences of the founder effect in the genetic structure of introduced island coral reef fish populations. Biol J Linn Soc 63:537-552

> Ponton D (2006) Is geometric morphometrics efficient for comparing otolith shape of different fish species? J Morphol 267:750-757

Pothin K, Gonzalez-Salas C, Chabanet P, Lecomte-Finiger R (2006) Distinction between Mulloidichthys flavolineatus juveniles from Reunion Island and Mauritius Island (south-west Indian Ocean) based on otolith morphometrics. J Fish Biol 69:38-53

Randall JE (1987) Introductions of marine fishes to the Hawaiian Islands. Bull Mar Sci 41:490-502

Reichenbacher B, Feulner GR, Schulz-Mirbach T (2009) Geographic variation in otolith morphology among freshwater populations of Aphanius dispar (Teleostei, Cyprinodontiformes) from the southeastern Arabian Peninsula. J Morphol 270:469-484

Rohlf FJ (2006) tpsDig, digitize landmarks and outlines. Department of Ecology and Evolution, State University of New York at Stony Brook, NY, available at http://life.bio. sunysb.edu/morph/

Rohlf FJ, Corti M (2000) Use of two-block partial leastsquares to study covariation in shape. Syst Biol 49: $740-753$

Rohlf FJ, Marcus LF (1993) A revolution in morphometrics. Trends Ecol Evol 8:129-132

Ryman N (1991) Conservation genetics considerations in fishery management. J Fish Biol 39:211-224

Schulz-Mirbach T, Stransky C, Schlickeisen J, Reichenbacher B (2008) Differences in otolith morphologies between surface- and cave-dwelling populations of Poecilia mexicana (Teleostei, Poeciliidae) reflect adaptations to life in an extreme habitat. Evol Ecol Res 10:537-558

Schumacher BD, Parrish JD (2005) Spatial relationships between an introduced snapper and native goatfishes on Hawaii reefs. Biol Inv 7:925-933

Sheets HD (2003) IMP CVAGen. Department of physics, Canisius College, Buffalo, NY, available at http://www3. canisius.edu/ sheets/moremorph.html

Sheets HD, Covino KM, Panasiewicz JM, Morris S (2006) Comparison of geometric morphometric outline methods in the discrimination of age-related differences in feather shape. Front Zool 3:15

> Simoneau M, Casselman JM, Fortin R (2000) Determining the effect of negative allometry (length/height relationship) on variation in otolith shape in lake trout (Salvelinus namaycush), using Fourier-series analysis. Can J Zool 78: 1597-1603

Söllner C, Burghammer M, Busch-Nentwich E, Berger J, Schwarz H, Riekel C, Nicolson T (2003) Control of crystal size and lattice formation by starmaker in otolith biomineralization. Science 302:282-286

> Stransky C (2005) Geographic variation of golden redfish (Sebastes marinus) and deep-sea redfish ( $S$. mentella) in the North Atlantic based on otolith shape analysis. ICES J Mar Sci 62:1691-1698 
Stransky C, MacLellan SE (2005) Species separation and zoogeography of redfish and rockfish (genus Sebastes) by otolith shape analysis. Can J Fish Aquat Sci 62: $2265-2276$

Strelcheck AJ, Fitzhugh GR, Coleman FC, Koenig CC (2003) Otolith-fish size relationship in juvenile gag (Mycteroperca microlepis) of the eastern Gulf of Mexico: a comparison of growth rates between laboratory and field populations. Fish Res 60:255-265

Tracey SR, Lyle JM, Duhamel G (2006) Application of elliptical Fourier analysis of otolith form as a tool for stock identification. Fish Res 77:138-147

Turan C (2000) Otolith shape and meristic analysis of herring

Editorial responsibility: John Choat,

Townsville, Queensland, Australia
(Clupea harengus) in the North-East Atlantic. Arch Fish Mar Res 48:213-225

Tuset VM, Rosin PL, Lombarte A (2006) Sagittal otolith shape used in the identification of fishes of the genus Serranus. Fish Res 81:316-325

Vignon M, Morat F, Galzin R, Sasal P (2008) Evidence for spatial limitation of the bluestripe snapper in French Polynesia from parasite and otolith shape analysis. J Fish Biol 73:2305-2320

Waples RS, Naish KA (2009) Genetic and evolutionary considerations in fishery management: research needs for the future. In: Beamish RJ, Rothschild BJ (eds) The future of fisheries science in North America, Vol 31. Fish \& Fisheries Series, Springer, p 427-451

Submitted: January 29, 2010; Accepted: May 7, 2010

Proofs received from author(s): July 17, 2010 